\title{
WEST AFRICA IN CONTEXT \\ Elections and the Challenges of Democratic Governance
}

\author{
Abdul Rahman Lamin \\ Dr Abdul Rahman Lamin is Programme Specialist, \\ Sector for Social and Human Sciences, UNESCO, Accra, Ghana \\ e-mail: ar.lamin@unesco.org
}

Somewhat paradoxically elections are fast becoming the new civil wars in Africa today. Almost two decades ago, when the so-called 'wave of democratisation' swept across the continent signaling an end to authoritarian rule and ushering in a new era of multiparty politics, there was a high degree of optimism that Africa was indeed now on track towards developing a democratic culture based on representative and participatory politics. This optimism was further reinforced by the transformation of the Organisation of African Unity (OAU) into the African Union (AU) and the AU's adoption in 2000 of a Constitutive Act which provided the normative direction to guide the continent on its democratic journey.

The AU Constitutive Act was substantively different both in character and content from the OAU Charter, which had governed relations among member states since the organisation was founded in 1963. For one thing, the Constitutive Act openly rejected unconstitutional changes of government and sanctioned external intervention in domestic matters on humanitarian grounds. This decision meant that in extreme cases state sovereignty, which had been jealously guarded throughout the OAU's lifespan, could be violated. This was clearly a significant departure and many observers argue that it contributed tremendously to the gradual evolution of democracy, which began with the introduction of multiparty politics on the continent, in the late 1980s and early 1990s.

The adoption by the AU of complementary normative instruments such as the African Charter on Democracy, Elections and Governance in 2003, along with the development of similar instruments at the sub-regional level, among them the ECOWAS Protocol on Democracy and Good Governance in 2001 and the SADC Protocol on Politics, Defence and Security Cooperation in 2001 (along with the SADC Principles and Guidelines on Governance and Democratic Elections in 2008), further consolidated the journey towards democratic governance. 
At the national level, as far back as the late 1980s and early 1990s liberal constitutions, with entrenched clauses protecting civil liberties and guarantees of free, fair and periodic elections, were promulgated across the continent. Thus, by the late 1990s and into the early years of the new millennium it appeared that Africa was indeed reinforcing its commitment to the rule of law and social justice by putting in place normative frameworks at national, sub-regional and continental levels which would gradually facilitate this process. In effect, democratic governance, with guarantees of multiparty elections, was becoming the norm rather than the exception by the time we entered the 21st century.

Beyond these normative and procedural gains, however, it is true that events on the continent in the past decade or so seem to suggest that multiparty democracy, and electoral politics more specifically, continue to pose significant challenges to regional stability. To be clear, recent elections all over the continent, and in West Africa in particular, have raised more questions than answers about the sustainability of and long-term prospects for democratic governance in the sub-region. It appears that contestation for political power among competing elites has become so fierce and the stakes so high that virtually no election in the sub-region today is likely to pass off without some kind of dispute in which one party or the other rejects the outcome.

A combination of factors both endogenous and exogenous could help explain this disturbing phenomenon. Among these are the heightened tensions and high stakes that surround elections in West Africa. We shall limit ourselves to one only. A common but somewhat complex factor frequently adduced by observers is the battle for control of state resources for the purpose of patronage, exacerbated by the increasing inequalities that permeate many countries in West Africa today. As a consequence, in many countries within the sub-region politics and, for that matter, the public service, has been transformed into a theatre in which individuals enrich themselves from the public purse.

It is all too common these days to find elites on all sides of the political divide arguing that it is their 'turn to eat', meaning that incumbents must make way for their opponents to occupy high office and help themselves to the contents of state coffers, and vice versa, when those same incumbents find themselves in opposition.

While the elites contest so fiercely to control state power the majority of the sub-region's peoples continue to wallow in misery and abject poverty, even in countries where the economy is said to be performing well and is growing at an alarming rate. The fact that such growth does not translate meaningfully into an improvement in the lives of ordinary people is manifested in the high rates of illiteracy, youth unemployment, massive urbanisation and little or no access by the majority to social goods, thus creating a recipe for disaster. 
It is not accidental, therefore, that elections, and the whole process of politicking, often create a heightened sense of tension that spills over into the post election period and leads to violence. The post-election violence in Côte d'Ivoire in 2010-11 and the boycott by Liberia's main opposition party of that country's second round of elections in 2011 and the subsequent violence, involving police and opposition supporters, are two recent reminders of how risky elections continue to be for both state and human security in West Africa.

The lessons of Liberia and Côte d'Ivoire could help inform other upcoming elections in the sub-region, in particular, that in Sierra Leone, a post-conflict country which has held two successful multiparty elections. The 2012 elections will be a decisive test of how far the country has come in building peace and consolidating democratic gains. These elections will be a fierce contest between the incumbent All People's Congress (APC), which came to power in 2007 on the platform of anti-corruption and improving the living conditions of ordinary citizens, and the Sierra Leone People's Party (SLPP), which, as the incumbent party, lost the 2007 election in circumstances its supporters consider suspicious at best.

Four years into the APC's rule the country's president, Ernest Bai Koroma, who, upon assuming power in 2007 had promised to govern the country like a 'business', faces a serious credibility challenge as high-profile officials in his government have either been convicted by the country's Anti Corruption Commission (ACC) or are being investigated for corruption. Among these officials is the current vice-president, Sam Sumana, whose office is alleged to have solicited bribes from investigative journalists posing as businessmen in return for lifting a government ban on logging, and the mayor of Freetown, the capital city, who, along with several top aides, has also been charged with multiple counts of corruption.

This suggestion of corruption in Koroma's government is further compounded by the high level of discontent among ordinary citizens, especially the young, unemployed and urbanised youth whose living conditions have deteriorated since the last elections. These are the issues Koroma and his APC will have to face as they seek a second mandate to govern. The SLPP, for its part, will have to overcome its image as an 'elitist' party far removed from the people, although if recent events are anything to go by the party seem to be receiving increasing attention from the public. An example of this is the popularity of its presidential candidate for the 2012 elections, Julius Maada Bio, a retired military general who was head of state in 1996 when Sierra Leone held its first multiparty elections after almost two decades of one-party dictatorship.

To be sure, Bio's candidacy remains a topic of hot debate in Sierra Leone, in part because of his military background, although he has not been formally 
accused of any wrongdoing. The point I seek to make here is that the stage is set for a very fierce contest in Sierra Leone in 2012 and the biggest test will be whether the incumbent will concede defeat and hand over power peacefully should he lose the election, as was the case in 2007 when the then ruling party lost and bowed out graciously. Whatever the outcome, Sierra Leone certainly has a lot to learn from the experience of other countries in the sub-region, in particular Liberia and Côte d'Ivoire.

In effect, what we have experienced in this sub-region in the past decade or so is a situation where many elections have ended up triggering more problems than they have been able to solve. While some have resulted in stalemate, with incumbents refusing to accept the 'will of the people' and transfer power to their opponents, as was the case with incumbent president Laurent Gbagbo's refusal to hand over power to his opponent, Allasane Ouattara, in Côte d'Ivoire, others have produced situations in which opposition parties have cried foul long before the first ballots have been cast, thus throwing into complete doubt the legitimacy of the outcome of those elections prior to their commencement, as was the case during the second round of Liberia's 2011 elections.

In the aftermath of such election-related disputes 'power-sharing' agreements, propagated by some as a model for accommodating all political interests in 'inclusive' governments, but regarded by others as 'elite pacts', have been crafted, with the assistance of the international community, to placate the belligerents. It remains to be seen whether this trend will continue in the coming years.

It is against this backdrop that contributions to this special edition of the Journal of Africa Elections should be seen. While the volume is not exhaustive in scope and content (for instance, there is no full-length article on Sierra Leone, notwithstanding the complexities of politics in the Mano River Union and no article on Liberia), it is hoped that it will be well received as a modest contribution to our understanding of the problems of elections in West Africa, within the broad context of democratic governance in the sub-region.

The contributors have provided us with a wide range of views on the issues, opportunities and challenges informing the democratic process in West Africa, analysing these through the lenses of elections. The subjects of the essays contained here include the tensions that emanate from the militarisation of politics and the implications thereof for democracy, as illustrated by the cases of Guinea and Niger; Nigeria's attempts to restore credibility to its electoral process, as seen in the 2011 elections, deemed to be generally free and fair; advocacy for a reform of Ghana's electoral system to avoid future conflicts and the challenges facing Ouattara in reconciling Côte d'Ivoire in the aftermath of the post-election crisis in that country. 
The gaps notwithstanding, this volume is both useful and timely in setting out the challenges of democracy and electoral politics in West Africa, with a view to better understanding them at the conceptual, political and policy levels. It is hoped that it will further inform political and policy responses designed to strengthen national, regional and international institutions as they attempt to prevent, manage, or, better still, resolve election-related disputes in the region. 